
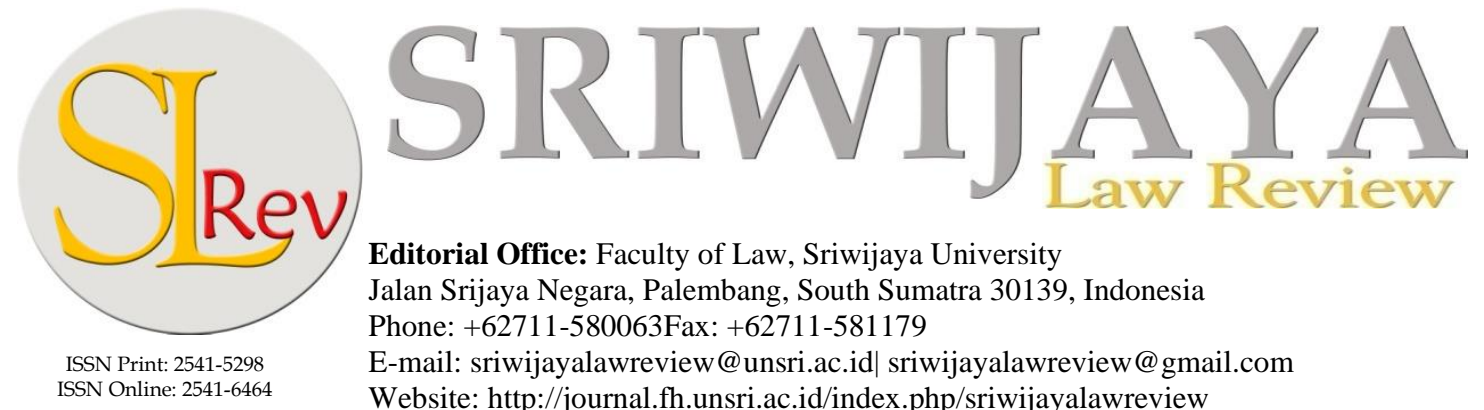

Editorial Office: Faculty of Law, Sriwijaya University

Jalan Srijaya Negara, Palembang, South Sumatra 30139, Indonesia

Phone: +62711-580063Fax: +62711-581179

E-mail: sriwijayalawreview@unsri.ac.id| sriwijayalawreview@gmail.com

Website: http://journal.fh.unsri.ac.id/index.php/sriwijayalawreview

\title{
The Fraud Rules in the Letter of Credit under Jordanian Legal System
}

\author{
Emad Mohammad Al-Amaren, ${ }^{a^{*}}$ Che Thalbi Bt Md. Ismail, ${ }^{\mathrm{b}}$ and Mohd Zakhiri bin Md. Nor ${ }^{\mathrm{b}}$ \\ a* Corresponding Author. Faculty of Law, Yarmouk University, Yarmouk, Jordan. Corresponding author: ama- \\ reenroma1993@gmail.com \\ b School of Law, Universiti Utara Malaysia, Kedah, Malaysia.
}

\begin{tabular}{ll}
\hline Article & Abstract \\
\hline Keywords: & $\begin{array}{l}\text { Letter of credit (L/C) has a massive role in expanding international trade op- } \\
\text { erations. It is considered the most secure and stable banking service to fi- } \\
\text { Fraud Rule; Jordanian } \\
\text { Courts; Jordanian Legal } \\
\text { nystem; Letter of Credit. } \\
\text { nance foreign trade operations such as import and export. As an international } \\
\text { users have to be aware of different approaches followed by domestic courts } \\
\text { while dealing with fraud at the international level. This paper aims to identi- } \\
\text { fy the fraud means under the fraud rule governing L/C and its impact on Jor- } \\
\text { dan's practice. By applying a qualitative and doctrinal legal approach, this }\end{array}$ \\
$\begin{array}{l}\text { Article History } \\
\text { Received: Feb 4, 2021; } \\
\text { Reviewed: Jul 13, 2021; } \\
\text { Accepted: Jul 21, 2021; } \\
\text { Published: Jul 31, 2021. } \\
\text { for the letter of credit (UCP No. 600). It also examines, via interviews with } \\
\text { Jordanian judges, the perceptions of the Jordanian courts' policy regarding } \\
\text { the fraud rule exception in L/C. The finding reveals that to protect the inter- } \\
\text { DOI: }\end{array}$ & $\begin{array}{l}\text { ests of all parties in a letter of credit transaction, Jordanian courts should ex- } \\
\text { tend the scope of fraud to cover sale contracts fraud in cases where bona fide } \\
\text { holder is involved and when a confirming bank is absent, or when the credit } \\
\text { amount has not been paid yet by the issuing bank. In respect of the bank } \\
\text { practices, such special provisions implemented to commercial code must be } \\
\text { 1058pp218-235 }\end{array}$ \\
\begin{tabular}{l} 
issued due to the lack of legal provisions of the L/C in Jordan legislation. \\
\hline O2021; This is an Open Access Research distributed under the term of the Creative Commons Attribution License
\end{tabular} \\
$\begin{array}{l}\text { (https://Creativecommons. } \\
\text { any medium, provided the original works is properly cited. }\end{array}$ \\
\hline
\end{tabular}

\section{INTRODUCTION}

"As long as there are commercial systems in place, there are those who try to manipulate these systems". ${ }^{1}$ Fraud is an ancient and well-known phenomenon in the world of business. Fraud is considered a controversial and confusing area as it touches the heart of the $\mathrm{L} / \mathrm{C}$ and forces the bank to look for the facts other than a complying presentation by the beneficiary to withhold

1 International Maritime Bureau of the ICC, Trade Finance Fraud: Understanding the Threats and Reducing the Risk: A Special Report (Paris: Distributed by ICC, 2002). 
payment. ${ }^{2}$ Letter of credit is deemed the heartbeat of international trade ${ }^{3}$ because it is a crucial trade instrument to finance international trade. ${ }^{4}$ It looks after the exporter and importer's interests, so it is considered an effective and safe approach for security of payment in international trade. $^{5}$

By utilizing a letter of credit, the buyer, in turn, is assured that the cargo value is to be paid if the seller provides evidence showing the discharging of the obligations assigned to him in the sale contract. ${ }^{6}$ On the other hand, Sellers get their money after the compliant documents are presented even though the bank's obligation towards the seller is unconditional as long as there is no clear evidence of fraud. While, on the other hand, in case of fraud, bank's has the right to withhold the sellers from receiving the value of the shipped goods, or further, withhold confirming or negotiating banks from honouring the payments to fraudulent sellers when there is a fraud committed in the transaction under the knowledge of the seller. ${ }^{7}$ Fraud is a significant risk that might face both Jordanian buyers and banks involved in credit transactions, as fraud is described, by some, as a 'cancer in international trade'. 8 Therefore, an intermediary bank (issuing, conforming, or negotiating) in the $\mathrm{L} / \mathrm{C}$ transaction may refuse to honour the payment when there is clear evidence of fraud committed by the seller. ${ }^{9}$

Jordanian judiciary applies the fraud rule as an exception to the independence principle. What is also applied in the Jordanian courts is that the rule of independence is not absolute. While there is an exception to the independence principle, that is when the process involves fraud. The L/C and the base contract are two separate contracts that are independent of each other. Therefore, the base contract is invalidated by fraud, and the relationship between the bank and the seller is also affected by such invalidity. Therefore, this paper aims at identifying the type of fraud that may invoke the fraud rule in Jordan and what is meant by fraud in the fraud rule in the law that governs letters of credit in Jordan.

2 Hamed Alavi, "Autonomy Principle and Fraud Exception in Documentary Letters of Credit, a Comparative Study between the United States and England," International and Comparative Law Review 15, no. 2 (2018): 47-68: 48, https://doi.org/10.1515/iclr-2016-0035.

3 Ali Mahmoud Abdallah Alrabei, "Perception of Jordanian Banks Employees on the Relationship between Accounting Information Quality (AIQ) and Documentary Credits," International Journal of Applied Business and Economic Research 15, no. 26 (2017): 409-419: 410.

4 Hamed Alavi, "Remedies to Fraud in Documentary Letters of Credit: A Comparative Perspective / Opravné Opatrenia Pri Podvodoch S Dokumentárnymi Akreditívami: Komparatívna Perspektíva,” EU Agrarian Law 5, no. 1 (2016): 1-13, https://doi.org/10.1515/eual-2016-0001.

5 Emad Mohammad Al-Amaren, Che Thalbi Bt Md Ismail, and Mohd Zakhiri Bin Md Nor, "The Blockchain Revolution: A Game-Changing in Letter of Credit (1/C)?," International Journal of Advanced Science and Technology 29, no. 3 (2020): 6052-58.

6 Emad Mohammad Al-Amaren, Che Thalbi Bt Md Ismail, and Mohd Zakhiri Bin Md Nor, Rachma Indriyani "Documentary Letter of Credit in Conventional and Islamic Banks in Jordan Documentary Letter of Credit in Conventional and Islamic Banks in Jordan," International Journal of Multidisciplinary Sciences and Advanced Technology 1, no 4 (2020): 1-15.

7 Nevin Meral, “The Fraud Exception In Documentary Credits: A Global Analysis,” Ankara Bar Review 39, no. 2 (2012): 41-76: 45.

8 Jan H Dalhuisen, Dalhuisen on International Commercial, Financial and Trade Law, 2nd ed. (Hart Publishing, 2004).

9 Felicity Monteiro, "Documentary Credits: The Autonomy Principle and the Fraud Exception: A Comparative Analysis of Common Law Approaches and Suggestions for New Zealand," Auckland University Law Review 13 (2007): 144-70: 148. 


\section{RESEARCH METHOD}

In examining standards followed by courts in Jordan about L/C under the Jordan system, qualitative and doctrinal legal approaches are used in this paper through using descriptive and content analysis. Furthermore, this paper has used a case approach by analyzing two Jordanian courts of cassation decisions. ${ }^{10}$ Jordanian judiciary has recently faced some fraud disputes in the letter of credit. ${ }^{11}$ For this reason, interviews were conducted with Jordanian judges to comprehensively understand the standard that the Jordanian courts have followed to apply the fraud rule exception in the letter of credit.

To answer this question, the researcher has studied the US law and the UNCITRAL convention approach. There are two reasons for choosing US law. First, the letter of credit fraud exception was recognized for the first time under the US legal system in the case of Sztejn v J Henry Schroder Banking Corporation. Second, the fraud rule in L/C is currently regulated in Article 5 of the US unified commercial code. This article is essential for being a statute covering $\mathrm{L} / \mathrm{C}$ fraud under the national law system and being a reliable and solid resource for some other national legal systems such as Jordan.

At the international stage, the UNCITRAL Convention for the standby letters of credit and independent guarantees addressed the problem of fraud in the letter of credit as a first global effort. Articles 15, 19, and 20 of the UNCITRAL Convention directly deal with fraudulent and abusive payment demands in standby L/C and independent guarantees. Therefore, the UNCITRAL Convention and Article 5/109 of the US unified commercial code is considered a supportive regulatory framework for UCP and the Jordanian legal system. Studying the US law and the UNCITRAL Convention approach helps the researchers explore the Jordanian path toward the fraud standard.

\section{ANALYSIS AND DISCUSSION}

The fraud exception mainly concerns when and why the autonomy principle in the letter of credit can be disabled if the victim of fraud has established clear evidence of fraud. ${ }^{12}$ Banks in the letter of credit do not examine whether the cargo exists or rely on documents representing the shipped goods. ${ }^{13}$ As a result, fraud in the letter of credit is a frequent problem for traders. Usually, banks cannot examine the extent of sincerity and the reality of a seller's documents. According to the principles governing letter of credit, banks should honour the payment when documents comply with credit conditions and terms unless they have absolute proof to suspect fraud. ${ }^{14}$ Letter of credit principles facilitates international trade operation by depending only on

10 Soehartono et al., "The Establishing Paradigm of Dominus Litis Principle in Indonesian Administrative Justice," Sriwijaya Law Review 5, no. 1 (2021): 42-55, https://doi.org/10.28946/slrev.Vol5.Iss1.603.pp 42-55.

11 The Jordanian Court of Cassation No. (1215/2005): concluded that the principle of independence ends in fraudulent fraud, where the supply of counterfeit goods with the submission of valid documents but does not represent the fact of the goods supplied.

12 Mohd Hwaidi, "Four Uncertainties around the Fraud Exception in Documentary Letters of Credit under English Law," The Journal of International Maritime Law 12, no. 732 (2012): 39-56:42.

13 Rushmila Bintay Rafique and A. Vijayalakshmi Venugopal, "Preventive Measures To Mitigate the Risk of Fraud in Letters of Credit Transactions in Malaysia," UUM Journal of Legal Studies 12, no. 2 (2021): 2749:32, https://doi.org/10.32890/uumjls2021.12.1.2.

14 Lamon Rutten, "A Primer on New Techniques Used by the Sophisticated Financial Fraudsters with Special Reference to Commodity Market Instruments," UNCTAD 11 (2003): 7. 
the compliance of the documents presented by a seller to be honoured. In the same context, letter of credit principles also facilitates fraudulent beneficiaries to submit bogus documents compliant with the conditions and terms of credit, while they are not so with the underlying sale contract. $^{15}$

\section{Reasons for the Emergence of Fraud in Letter of Credit Operations}

There are several reasons for fraud to occur in the letter of credit transactions, such as:

\section{Sole Use of Documents}

According to UCP 600 article 34, banks are not obligated to check the genuineness and accuracy of the seller's documents. ${ }^{16}$ However, the sole use of documents is one of the most wellknown and essential reasons for fraud in the letter of credit. ${ }^{17}$ For example, an ill-fated beneficiary can manufacture and ship goods with low quality or less quantity, then modify the bill of lading and the certificate of origin to match the credit terms and conditions to obtain payment non-genuine documents. ${ }^{18}$

\section{Geographical Distance}

The second reason why the letter of credit can be abused in international business transactions is that parties are located in different states, and goods usually reach the destination's port after obtaining the payment. As a result, the fraudulent seller can have enough time to receive payment from the bank and then disappear before his/her fraudulent activity is discovered. ${ }^{19}$ From the researcher's point of view, the reason behind this is that ships, unlike other means of transportation, take days to reach their destinations. It means that fraudsters get time to cover their tracks.

\section{The Lack of Efficiency in Prosecution System Worldwide}

In addition to the above reasons, the weakens of the prosecution system, whether at the domestic or international level, are notable reasons for the letter of credit fraud. Despite the enormous economic loss that the party defrauded may face due to the fraudulent party act in international trade, no international regulations have been established to facilitate the prosecution and arrest of such fraudsters. The fraudulent party usually disappears after receiving the payment, and neither banks nor buyers can find him/her, even in cases where the fraudster's places are known. Moreover, it is difficult to issue legal action against him/her since he/she is staying in different states. ${ }^{20}$

\section{Containerization}

Container fraud usually happens when the seller sends inferior goods to the buyer. ${ }^{21}$ The invention of containers also contributes to the problem of fraud in international trade. As a result of

15 Hamed Alavi, "Mitigating the Risk of Fraud in Documentary Letters of Credit," Baltic Journal of European Studies 6, no. 1 (2016): 139-56.

16 Meral, "The Fraud Exception in Documentary Credits: A Global Analysis."

17 Yanan Zhang, Approaches to Resolving the International Documentary Letters of Credit Fraud Issue, 2011.

18 Shohana Islam, and Shamim Ahamed, "Preventing Letter of Credit Fraud," DIU Journal of Business and Economics 3, no. 2 (2008): 1-12:7. http://hdl.handle.net/20.500.11948/667.

19 Zhang, Approaches to Resolving the International Documentary Letters of Credit Fraud Issue.

20 Islam, Shohana and Ahamed, "Preventing Letter of Credit Fraud."

21 Rosmawani CheHashim and Nurul Shahnaz Mahdzan, "Fraud in Letter of Credit Transactions: The Experience of Malaysian Bankers," International Journal of Law, Crime and Justice 42, no. 3 (2014): 224-236:229, https://doi.org/10.1016/j.ijlcj.2014.01.008. 
using containers, it has become challenging to determine the imported goods' quantity and quality. ${ }^{22}$ Further, the reality of the imported goods is discovered after the goods reach the destination port and after the seller obtains the payment from the bank due to geographical distance. $^{23}$

\section{Diversity of Criteria on Fraud}

As a result of the differences in the legal regime between states, every state applies different criteria on the letter of credit fraud crime. ${ }^{24}$ On the one hand, some countries apply civil code regulations on the letter of credit fraud crime without paying any attention to the fraud's criminal responsibility. ${ }^{25}$ On the other hand, some countries apply criminal code regulation on credit fraud crime to punish fraudsters, such as; United States. ${ }^{26}$ As a result, it is not easy to prove fraud in the letter of credit in most states and apply the fraud exception rules in civil litigation, therefore obtaining a stop-payment court order. ${ }^{27}$ Furthermore, regarding injunctions or stopping-payment court orders, there are no international regulations for its applications.

\section{Fraud Exception Restrictions}

Fraud exception is well-known to be very restricted in application, as courts are very cautious not to disturb the letter of credit autonomy. The fraud establishment standard is hard to prove, as fraud mere allegation or suspicion is insufficient to obtain a stopping-payment court order. As for courts to consider activation of fraud exception, fraud has to be based on a document to withhold bank from honouring the payment, and payment cannot be withheld due to inferior goods or delayed delivery basis. ${ }^{28}$ Therefore, to stop a fraudulent seller from obtaining compensation, the fraud establishment proof needs to be precise (material) and based on a document only. Furthermore, the beneficiary should commit the fraud by himself or by a third party under his/her knowledge.

The fraud phenomenon is timeless and widespread, and it is found all over the globe. ${ }^{29}$ The UNCITRAL report has provided a list including fraud schemes that might face an applicant due to the banks' reliance on strict compliance principal only in the L/C context. ${ }^{30}$ Commonly, fre-

22 Islam, Shohana and Ahamed, "Preventing Letter of Credit Fraud."

23 Meral, "The Fraud Exception in Documentary Credits: A Global Analysis."

24 Baojie Wang, "Discussion on Internationalization of Punishment of L/C Fraud and Legal Remedy," Politics and Law 87 (2005): 87-88.

25 Zhang, Approaches to Resolving the International Documentary Letters of Credit Fraud Issue.

26 See, Rolf Schütze and Gabriele Fontane, "Documentary Credit Law throughout the World (Annotated Legislation from more than 35 Countries)" (Paris: ICC Publishing, 2001), 34-36. Mentioned in Yanan Zhang, "Approaches to Resolving the International Documentary Letters of Credit Fraud Issue." 2011, 26.

27 See, Lu, "Comparative Study on L/C Fraud Exception in Common Law System", Jianghai Academic Journal (Bimonthly), no. 1 (2008): 226. Mentioned in Yanan Zhang, "Approaches to Resolving the International Documentary Letters of Credit Fraud Issue.” 2011, 26.

28 Islam, Shohana and Ahamed, "Preventing Letter of Credit Fraud."

29 Yanan Zhang, "Can Soft Clauses in Letter of Credit Transactions Be Considered Letter of Credit Fraud in China ?," Nordic Journal of Commercial Law 15, no. 1 (2011): 1-20:2.

30 Rutten, "A Primer on New Techniques Used by the Sophisticated Financial Fraudsters with Special Reference to Commodity Market Instruments." UNCTAD/ DITC/COM/39, (2003), 7. The most common types of fraud that an applicant can face in the letter of credit, according to the UNCTAD report, are; 1) Cargo is nonexistent; the beneficiary falsifies the documents to obtain payment from the bank. 2) Cargo is of inferior quality or quantity. 3) The same cargo is sold to two or more parties. 4) Double bills of lading are issued for the same cargo. 
quent victims of L/C fraud are buyers, banks, and even insurance companies. ${ }^{31}$ Fraudsters can invest years and spend a large amount of money to create a good reputation between international trader's society, then, committed a big fraud operation, leaving other parties in a letter of credit in enormous economic loss. ${ }^{32}$

\section{The Fraud Rule Standard under the US Law}

Article 5 of the unified commercial code of the United States governs the operation of letters of credit besides the case law. ${ }^{33}$ The United States (UCC) unified commercial code, article 5, is specially designed to letters of credit. The US legislator has followed the goal of finding a new technique for additional harmonization of the law of US with other international regulations, as well as flexibility in practice, and to keep up with the technological changes worldwide and maintain the position of letter of credit as an essential method of payment in international trade. ${ }^{34}$

Also, Article 5 of the UCC is unique because it contains a special provision for fraud exception in the letter of credit covering situations essential for granting an interlocutory injunction. Article 5-109 of the UCC settled down one of the most important questions under the fraud exception rule in the letter of credit, which is the scope of the fraud exception rule. According to article 5-109, the fraud rule exception is applicable in both the documents and the underlying sale contract between buyers and sellers. In addition, this article requests material evidence to issue an interlocutory injunction. Nevertheless, article 5-109 of the UCC does not express what is meant for fraud to be material. ${ }^{35}$ Article 5-109 of the UCC defined material fraud as "the beneficiary has no colourable (meaningful) right to expect honour, and where there is no basis in fact to support such a right to honour". 36

Although this standard is similar to egregious fraud, the official comment on article 5-109 of the UCC has used the name 'material fraud' to describe the standard needed under this article. It means, to grant an interlocutory injunction under US law, the fraud must be significant and material. In different words, the fraudulent aspect of the submitted documents must be noticed and does not only show a state of mind of the seller, or the act of fraud issued by the fraudster must be significant to the other party in the underlying sale contract. ${ }^{37}$

The injunction is the primary remedy for the letter of credit fraud in US law according to article 5-109 of the UCC. The injunction has been considered the primary remedy because if the bank bounder the payment, the applicant will have a limited opportunity to get his/her money back from the fraudulent beneficiary. ${ }^{38}$

31 Alavi, "Autonomy Principle and Fraud Exception in Documentary Letters of Credit, a Comparative Study between the United States and England."

32 Rutten, "A Primer on New Techniques Used by the Sophisticated Financial Fraudsters with Special Reference to Commodity Market Instruments."

33 Yanan Zhang, "Approaches to Resolving the International Documentary Letters of Credit Fraud Issue.” 2011, 25.

34 Alavi, "Remedies to Fraud in Documentary Letters of Credit: A Comparative Perspective / Opravné Opatrenia Pri Podvodoch S Dokumentárnymi Akreditívami: Komparatívna Perspektíva."

35 Alavi.

36 UCC Article 5 Letters of Credit, UCC 5-109 Forgery and Fraud, Official Comment 1.

37 Ioanna Tolia, "Recognized Exceptions to the Autonomy Principle in Documentary Letters of Credit : A Global Analysis," no. February (2018).

38 Meral, "The Fraud Exception in Documentary Credits: A Global Analysis." 
Neither article 5-109 of the UCC nor its official comments pay any attention to the beneficiary's intention to defraud. As a result, article 5-109 of the UCC has focused only on the seriousness of fraud and its effect on the transaction, not on the seller's state of mind. ${ }^{39}$ From article 5-109 of the UCC, it is evident that proof of high standard is needed, and it is not enough to have a mere allegation of fraud to grant an injunction to the applicant. Such injunction under US law is granted in a situation where the buyer provides material evidence, and that is to protect the independence principle in $\mathrm{L} / / \mathrm{C}$ transaction.

Texts of articles 5-109 of the UCC is very inspiring. It does not only state fraud standards under the $\mathrm{L} / \mathrm{C}$ context but also sets an exceptional standard of $\mathrm{L} / \mathrm{C}$ fraud, a fit standard formed specially to tackle down fraud in the transactions of the L/C. The fifth article of the UCC, Section 5-109, now represents the most advanced regulation to fight fraud under letters of credit in the world countries' common laws. ${ }^{40}$

\section{The Fraud Rule Standard under the UNCITRAL Convention}

In 1995, the United Nations Commission on international trade had issued the UNCITRAL Convention on independent guarantees and standby letters of credit, aiming to facilitate independent guarantees and standby $\mathrm{L} / \mathrm{C}$ in global trade. ${ }^{41}$ It is worth mentioning that, UNCITRAL Convention does not use the "terms 'fraud' in the convention. ${ }^{42}$ The reason behind that is to prevent any misunderstanding that might occur because of various clarifications in other legal systems. Article (15) directs the beneficiary in making the demand under standby L/C and independent guarantees. It comes back to conditions under which the demand of the beneficiary can be withheld. ${ }^{43}$

Through the convention's articles, it is evident that the convention requests clear evidence as proof of fraudulent act without paying any attention to the seller's state of mind. That is exactly what is in article 5 of the UCC. ${ }^{44}$ While article 19 states the substantive grounds to invoke the fraud rule, and article 20 provides court action with possibilities under the title of provisional court measures. Nevertheless, there are some criticisms directed at the convention. First, the list of the fraudulent activity to activate the fraud rule is exhaustive, or it is just sampled for further comparison. ${ }^{45}$ To apply the rules of the UNCITRAL Convention on independent guarantees and standby letters of credit, the contracted parties should check if their countries have already accepted the convention to have its effect. ${ }^{46}$ Finally, the scope of the convention is lim-

39 Ross Buckley, "The 1993 Revision of the Uniform Customs and Practice for Documentary Credits," The George Washington Journal of International Law and Economics 28 (1994): 265.

40 Gao Xiang and Ross P. Buckley, "A Comparative Analysis of the Standard of Fraud Required Under the Fraud Rule in Letter of Credit Law," Duke Journal of Comparative \& International Law 13 (2003): 293-336.

41 Zhang, Approaches to Resolving the International Documentary Letters of Credit Fraud Issue.

42 Gao Xiang and Ross. P Buckley, "A Comparative Analysis of the Standard of Fraud Required Under the Fraud Rule in Letter of Credit Law," Duke Journal Of Comparative \& International Law 13 (2003): 293-336:332.

43 United Nations, "United Nations Convention on Independent Guarantees and Standby Letters of Credit". (1996), article 15; "the beneficiary, when demanding payment, is deemed to certify that the demand is not in bad faith (for example by providing confirmation letters from an authorized inspection firm regarding the compliance of shipped consignment with terms of LC and that none of the elements referred to in subparagraphs (a), (b) and (c) of paragraph 1 of article 19 are present".

44 Xiang and Buckley, "A Comparative Analysis of the Standard of Fraud Required Under the Fraud Rule in Letter of Credit Law."

45 Xiang and Buckley.

46 Meral, "The Fraud Exception in Documentary Credits: A Global Analysis." 
ited to standby letters of credit and independent guarantees. Even if the UCP deals with standby letters of credit similarly to L/C commercially, there are few differences between them, so it should not be adopted directly. ${ }^{47}$

Despite all previous comments on the convention, it is still able to present a decent sample for the International Chamber of Commerce (ICC) to regulate the rules about fraud in its next UCP version. Therefore, the convention's provisions can be taken to measure the ICC for additional reform in the UCP to improve the fraud rule. ${ }^{48}$ Buckley and Gao argue that if the scope of the UCP version is further than now, its effect would be more substantial. However, they still see it as the first step towards better solutions at the international level rather than leaving it to national courts. ${ }^{49}$

The researcher concludes that the UNCITRAL convention about independent guarantees and standby letters of credit successfully addressed the main aspects of fraud rule established by national and international courts. The types of fraudulent acts committed by the beneficiary are listed in Article 19 (1). In addition, the scope of the fraud is not limited to the documents but goes further to the sales contract. The convention also offers guidance about actions that victims of fraud can take through payment withholding or by refusing to honour presentation if the victim is the bank or the applicant and applying for an interlocutory injunction at the competent court to prevent issuing bank from honouring the fraudulent beneficiary.

\section{The Fraud Rule under the Jordanian Law}

This part of the research covers the fraud scope, the fraud standard and L/C fraud Injunctions under the standard followed by Jordanian law.

\section{Fraud Scope in Jordan}

Through examining the decisions issued by Jordanian jurisdiction, the researcher found that the fraud scope in Jordan covers fraud in documents and the underlying contract, as UNCITRAL convention on independent guarantees and standby letters of credit and article 5 of UCC do. In decision no. 835/2004 issued by the Jordan court of cassation (JCC), it found that sale contract fraud can interrupt the independence principle. Furthermore, the esteemed court has given the banks the right to withhold the payment to the beneficiary and that when a martial proof of fraud is available before the bank honours the payment. According to the standard established by the Jordanian judiciary, Jordanian banks under the Jordanian fraud standard test need clear and material evidence of fraud to justify their non-willing to pay the fraudulent beneficiary. The standard established by the Jordanian judiciary is rational because it provides full protection for the bank to justify its deferment of payment to the beneficiary if there is any litigation against the bank in the future.

The events of the case are summed up as a buyer from Jordan concluded a sale contract with a Canadian seller to import medical equipment and modern furniture for the benefit of the Jordanian buyer. Based on that, the Jordanian buyer asked the Housing bank of Jordan to open a letter of credit in favour of the Canadian seller. The Jordan Housing Bank opened a credit for

47 Ross P Buckley and Xiang Gao, "The Development Of The Fraud Rule In Letter Of Credit Law: The Journey So Far And The Road Ahead," U. Pa. J. Int'l Econ. L 23, no. 4 (2014): 663-712.

48 Meral, "The Fraud Exception in Documentary Credits: A Global Analysis."

49 Ross P Buckley and Xiang Gao, "Development of the Fraud Rule in Documentary Credit Law: The Journey So Far and the Road Ahead," U. Pa. J. Int'l Econ. L. 23 (2002): 663. 
the benefit of the Canadian seller, which was confirmed through a Canadian bank. The underlying sale contract agreement included that the Canadian seller has to ship nine containers contain medical equipment and modern furniture.

Nevertheless, when the goods arrived at the port of destination, the customs report shows that only five containers had reached the port. These five containers contain unusable materials. Based on the report of the port customs, the applicant approached the competent court to withhold the Housing Bank of Jordan from honouring the payment. The district court issued a court order in favour of the Jordanian applicant to withhold the Housing Bank of Jordan from honouring the payment, and further, the court of appeal did so. When the case reached the JCC, it confirmed what the lower courts had concluded. ${ }^{50}$

Another case ruled by the JCC demonstrated the Jordanian situation regarding the scope of fraud rule exception with further simplicity. The events of the case are summed up as: A buyer from Jordan concluded a contract with a seller from England to supply him with certain oil materials. Based on that, the Jordanian buyer asked the Export and Finance Bank of Jordan to open a letter of credit in favour of the English seller. The Jordan Export and Finance Bank opened a letter of credit for the benefit of the English seller, which was confirmed through an England bank.

The credit terms required the English seller to send the documents that represent the ownership of the goods to the conforming bank to obtain the payment. What is suspicious about the required documents is that none of the Jordanian applicant's documents showed what the contracted goods are. The Jordanian buyer just requested the documents, which usually any buyer asks for in an L/C transaction. When the goods arrived at Jordanian port, the Royal Scientific Society report shows that the containers were filled with unusable oil mixed with water and other chemicals.

Based on the Royal Scientific Society report, the Jordanian buyer approached the Jordanian Competent Court to withhold Jordan's Export and Finance Bank from honouring the payment. The district court issued a court order in favour of the Jordanian applicant to withhold Jordan's Export and Finance bank from honouring the payment, and further, the court of appeal did so. When the case reached the Court of Cassation, it stated that;

"While the documents required by the letter of credit match in both facial and technical aspects, they are forged because they included unreal information about the contracted oil material. If the documentary letter of credit and the underlying sale contract are two independent contracts, this would not be the case anymore where there is fraud. Fraud invalidates the sale contract, and this would extend to the bank's relationship with the seller." 51

Remarkably, in its decision number 835/2004 and decision number 1215/2005, JCC has not found any problems to examine the base contract to issue it decision whether fraud had been committed in the transaction or not. ${ }^{52}$ Although the English and Canadian sellers in both cases had submitted the required documents according to the credit terms and conditions, this was not considered an obstacle in front of the competent court from intervening and inspecting the base contract to decide whether fraud had been committed in the transaction.

50 A decision issued by Jordanian Court of Cassation, no. 835/2004.

51 A decision issued by Jordanian Court of Cassation, no. 1215/2005.

52 Kamal Jamal Awad Alawamleh, "Documentary Credits and Independent Guarantees: A Critique of the 'Fraud Exception' Position in English and Jordanian Law" (University of Central Lancashire, 2013). 
When the researcher asks the Jordanian judge if the fraud that can stop the payment is a fraud in documents or the base contract or both, Judge Zaid Sanosi stated that a letter of credit relies on documents, and all parties in their relations consider documents to be a priority. The fraud that should stop payment is only the documents fraud. The courts should look only at the document's fraud. The expansion of the reduction of the rule of independence, in view of the underlying contract, disables the task of a letter of credit as a tool for the settlement of international sales. ${ }^{53}$

While judge Mohammed Al Ameren's opinion is different in this matter, he stated that: The judge should stop the entire process wherever fraud is discovered and cannot be narrowed because it would waste merchants' rights. The judge does not see any importance in restricting the place of fraud. It is crucial to stop fraud wherever it exists, which is precisely the judge's task. ${ }^{54}$

Sharing the same perspective with judge Mohammed Al Amareen, Judge Saeed Ajlouni provided that: Fraud is a fraud wherever it exists, whether in the base contract or documents and narrowing this to documents only leads to not punishing the fraudster in cases where the fraud is based on documents. Furthermore, limiting this to documents will push traders to abandon letters of credit because it will become a contract tainted by fraud. ${ }^{55}$

According to the interview with the Jordanian judges, fraud scope is an unresolved matter among Jordanian judges. The researcher supports judge Mohammed Al Amareen, and Judge Saeed Ajlouni's perspective as fraud is a fraud wherever it exists, whether in the base contract or documents. The reason behind this is because this practice is safer and fairer to the applicant, who may suffer from a massive loss if the fraud is in the goods and not in the documents.

\section{The Beneficiary Intention to Defraud}

All the interviewed judges agreed that the beneficiary's intent, whether fraudulent or not, should not be taken as an obstacle to withhold the bank from honouring the payment based on non-genuine or false documents. Judge Zaid Sanosi, judge Mohammed Al Amareen, and Judge Saeed Ajlouni believed that the unoriginality of any document is enough evidence for the banks to withhold the payment. For example, Judge Saeed Ajlouni stated that:

"I cannot entirely agree with the stipulation that the beneficiary intends to defraud. It is difficult to view the fraud intent as a condition for the declaration of fraud due to the difficulty of detecting the intention.

Therefore, the judge does not take intention in the event of fraud when there is a dispute in the letter of credit." 56

The interviewed Jordanian judges emphasize that the beneficiary's fraudulent intention is controlled by the judge's discretion and the facts of the case. They emphasize again and again that judges should search for material and clear proof of fraud. They should not care whether there is a fraudulent intention because applying this standard in $\mathrm{L} / \mathrm{C}$ would deprive Jordanian buyers of the needed protection in international trade. ${ }^{57}$

The researcher concludes that the Jordanian approach regarding the fraud standard is not complicated to fulfil. The fraud scope in Jordan is extended to cover fraud on documents or sale contracts. Furthermore, the victim of the fraud has to provide material and clear proof of

\footnotetext{
Judge Mohammed Al Amareen, Interview by author, Irbid-Jordan, August 13, 2019.

54 Judge Zaid Sanosi, Interview by author, Irbid-Jordan, August 12, 2019.

55 Judge Saeed Ajlouni, Interview by author, Irbid-Jordan, August 14, 2019.

56 Judge Saeed Ajlouni, Interview by author, Irbid-Jordan, August 14, 2019.

57 Judge Mohammed Al Amareen, Judge Zaid Sanosi and Judge Saeed Ajlouni.
} 
fraud committed by the seller or by others under the seller's knowledge. At the same time, the intent of fraud can be discovered from the facts of the case. The Jordanian view contrasts with the United Kingdom's conventional view regarding fraud rule exception in the letter of credit. ${ }^{58}$ In this matter, the UK law view that the scope of fraud is only restricted to cover the fraud on documents only. ${ }^{59}$ Moreover, UK law required the beneficiary himself or under his knowledge to commit the fraudulent act. ${ }^{60}$

\section{The General Fraud Civil Act Rules in Jordan}

The Jordanian commercial code did not regulate L/C transactions. Nevertheless, the civil law rules indicate the general fraud provisions in a commercial transaction, as Article 145 and 148 of the Jordanian civil law states that;

"If a contracting party commits a fraud towards the other party, the latter can terminate the contract if it has been proved that such a fraud is material". ${ }^{6}$ "If fraud derives from a third party other than the contracting parties and the deceived party can prove that such a fraud has been committed under the knowledge of the other contracting party, the deceived party can withdraw the contract". ${ }^{62}$

When the researcher asked the Jordanian judges if the Jordanian Civil Code, which addresses general fraud rules, can be applied to L/C fraud, judge Saeed Ajlouni stated that these rules contradict the principles of the established commercial law because commercial contracts, such as documentary credit, have unique nature that should distinguish them from others and set their own rules. ${ }^{63}$ Judge Zaid Sanosi then added that Articles (145 and 148) in the Jordanian Civil Code stipulate the basic rules of fraud. The judge considers that applying such regulation is contrary to the principles of commercial law because the letter of credit is of an exceptional nature and needs special rules. ${ }^{64}$

The interviewed Jordanian judges have found that it is challenging to apply the general fraud provisions addressed in civil law on the letter of credit, as applying such rules would contradict the letter of credit mechanism because it is mainly designed to tackle fraud in civil matters commercial issues.

\section{Injunctions in Jordan}

The Jordanian civil procedure law no. 24 of 1988 has stipulated few rules to deal with injunctions. Article 32 of The Jordanian civil procedure law states that:

"The judge of urgent matters, without permanently prejudicing the parties' rights, may grant a temporary injunction until a full hearing court can adjudicate the disputed matter if requested to grant an injunction in a case that the matter is urgent and the right of the party seeking an injunction would be lost if no judiciary relief is granted in that time". ${ }^{65}$

Remarkably, Article 32 states that injunction to be granted, an element of urgency should occur even though the judge of urgent matters determines the disputed urgency. ${ }^{66}$ It is worth

58 Kamal Jamal Alawamleh and Shadi Helo Abu Helo, "Fraud in the Documents and the Underlying Contract in Letters of Credit under Jordanian and English Law: A New Prerequisite?" Journal of Financial Crime, 2020.

59 Zaid Aladwan, "The Implementation of the Fraud Exception Rule: A Comparative Study," Journal of Financial Crime 27, no. 3 (2020): 977-93.

60 Chathura Warnasuriya, "Fraud Unravels All; Do Fraudulent Documents Invalidate A Letter of Credit?," KDU Law Journal 1, no. 1 (2021): 17-31: 28. http://ir.kdu.ac.lk/handle/345/3803.

61 Jordanian Civil Law No. 43 of 1976.

62 Jordanian Civil Law No. 43 of 1976.

63 Judge Saeed Ajlouni, Interview by author, Irbid-Jordan, August 14, 2019.

64 Judge Zaid Sanosi, Interview by author, Irbid-Jordan, August 12, 2019.

65 Jordanian Civil Procedure Act, Number 24 of the year 1988

66 Isrā' Al Kharābshih, "al-ghuṣh fì al 'qd al-āsāsì kā-istithnā' 'lá mabdā' al- ìstiqlāl fì al-i 'timād al-mustanadī." (Master's Thesis., University of Jordan, 2010), 94. http://search.mandumah.com/Record/555162. 
mentioning that seeking an injunction to withhold payment in a letter of a credit transaction based on fraud is often considered an urgent matter in the Jordanian judiciary ${ }^{67}$ because of the potentiality of loss for the buyer, for example, makes it an urgent matter. ${ }^{68}$

Further, according to Article 32, the judge of urgent matters who grants an injunction to the injunction demanded grants it temporarily until the competent court can hear the entire disputed case without depriving other parties of their judicial rights. Therefore, due to the absence of a special provision that regulates letter of credit in general and the injunctions procedure in the letter of credit in particular, Jordanian applicant can seek this kind of judiciary relief stipulated in Article 32 to deprive the other party of gathering the fruit of his fraudulent acts. ${ }^{69}$

In this regard, Judge Mohammed Al Amareen affirmed that he follows Article 32 of the civil procedure law regarding urgent cases. The custom established in the Jordanian courts considers the order to stop payment in the documentary credit process as a matter of urgency. It is because it arranges for the loss of the merchant's rights in the non-suspension of payment. Based on the above, the judge mentions the conditions for granting a court order to stop payment as follows:

First, there must be unmistakable evidence of fraud. It should be evident from the merits of the case, stressing that the judiciary should not pay attention to the existence of the intention or the place of fraud. Second, the only explanation is the occurrence of fraud, whether it is the beneficiary's work or anyone else. Third: There should be no bona fide holder involved because his rights will be affected if the stop payment order is granted. ${ }^{70}$

While judge Saeed Ajlouni argues that he issues a court order to stop payment if not stopping payment would cause a significant loss to the buyer even if there is a bona fide holder involved. He added that: The rule of fraud is an exception in all commercial matters, including the letter of credit as part of the commercial system, based on the legal rule that the fraud corrupts everything, and what is built on falsehood is null. ${ }^{71}$

The researchers find it necessary to say that the Jordanian judiciary's approach towards fraud standards has not placed any obstacles in front of the Jordanian applicant who seeks to withhold the bank from honouring the payment based on fraud. However, Jordanian courts have not fully implemented the Jordanian fraud standard test in case of an injunction. Neither Jordanian JCC decision number 835/2004 nor decision number 1215/2005. ${ }^{72}$

Sequentially, the test which the Jordanian courts have applied is similar to the 'only realistic inference' test. Under this standard of test, the Jordanian account parties have to prove that the sole rational clarification is that the fraud has occurred in the L/C transaction based on the presented documents and the transaction evidence. It is indisputable that applying the solely real reason test is a positive step taken by the Jordanian courts. Applying this test provides

67 According to the information gathered from the interview with Judge Mohammed Al Amareen, Interview by author, Irbid-Jordan, August 13, 2019

68 Alawamleh, "Documentary Credits and Independent Guarantees: A Critique of the 'Fraud Exception' Position in English and Jordanian Law."

69 Mạ̣mūd al-Qựāh, qānūn āuṣūl al-muḥākamāt al-madanyah watanzīm al-qaḍā' ’̀ fì al-āurdun" (Amman: Dār al-Thaqāfah for Publishing and Distributing, 1992), 75.

70 Judge Mohammed Al Amareen, Interview by author, Irbid-Jordan, August 13, 2019.

71 Judge Saeed Ajlouni, Interview by author, Irbid-Jordan, August 14, 2019.

72 Alawamleh, "Documentary Credits and Independent Guarantees: A Critique of the 'Fraud Exception' Position in English and Jordanian Law." 
practical rather than theoretical means to grant an injunction. ${ }^{73}$ However, there is a critical point that Jordanian courts should pay attention to, which is the existence of a holder in due course.

In case no. 1215/2005, the JCC had utterly ignored that the English confirming bank had already fulfilled its obligations and honoured the payment when the applicant granted the injunction. The Jordanian court of cassation had neglected entirely that and issued an injunction to withhold Jordan Export and Finance Bank from reimbursing the English confirming bank, which had appropriately fulfilled the obligation delegated to it. ${ }^{74}$

In a similar context, in case no. 835/2004, the JCC also ignored that when the court order was granted to the applicant to withhold the Housing Bank of Jordan from honouring the payment, the Canadian confirming bank had already fulfilled its obligations. Even though the Canadian confirming bank had frequently, during the three-level of the trial, reminded the honourable courts of the confirming bank's unique role in the letter of credit, but the estimated courts did not pay any attention. ${ }^{75}$ Remarkably, the same test has been applied where no confirming bank is existed, as in the district court of Amman decision no. 407/2009, where the applicant has granted a court order to withhold the issuing bank from honouring the payment. ${ }^{76}$

Through analysing the decisions issued by the Jordanian courts of various levels (First Instance, Appeal, Cassation), ${ }^{77}$ Jordanian courts have applied the solely real reason test where no bona fide holder is involved and where a bona fide holder is involved. On the one hand, applying this test where no bona fide holder is involved is considered an effective and successful approach taken by the Jordanian courts. Applying this test in the absence of a bona fide holder provides a more practical means to grant the victim of fraud a court order to withhold the payment. While, on the other hand, applying the solely real reason test where a bona fide holder is involved contradict article (35) of the UCP 600, which stated that: confirming bank must honour or negotiate, or reimburse the nominated bank or confirming bank under all circumstances.

${ }^{78}$ Furthermore, applying this test where a bona fide holder is involved will threaten the conforming and issuing bank's position in the transaction, especially when the conforming or issuing bank have fulfilled their obligation in the L/C by honouring the payment.

Finally, applying the fraud standard test established by Jordanian courts would potentially demolish the independence principle application in the L/C context. For that, Jordanian courts must pay attention to such an approach, as it is recommended in cases where there is no bona fide holder, while it should be avoided in cases where a bona fide holder is involved.

\section{CONCLUSION}

According to the custom established by the Jordanian judiciary, the fraud exception means an exception in which Jordanian banks have the opportunity to refuse to honour the payment to the beneficiary based on a court order issued by a competent court (injunction), and that when clear

\section{Alawamleh.}

4 A decision issued by Jordanian Court of Cassation, no. 1215/ 2005

75 A decision issued by Jordanian Court of Cassation, no. 835/ 2004

76 District court of Amman decision no. 407 of 2009

77 District court of Amman decision no. 407 of 2009, decision no. 835/2004 and decision no. 1215/2005 issued by the Jordanian court of cassation.

78 International Chamber of Commerce, Documentary Credits Regulations "Uniform Custom and Practice", No. 600 (2007). 
and material evidence of fraud is established in documents or the underlying sale contract, whether this fraudulent act is committed by the beneficiary or by others under his knowledge. In this regard, it is unarguable that the standard established by the Jordanian judiciary is rational as it provides total protection for the bank to justify its deferment of payment to the beneficiary if there is any litigation against the bank in the future. In addition, the standard established by the Jordanian judiciary protects the buyer from any significant losses that he/she may incur as a result of restricting the fraud exception to documents only.

The Jordanian approach regarding the fraud standard is not hard to be achieved similar to the US approach. The Jordanian judiciary has successfully extended the scope of the fraud rule to cover documents fraud and fraud in the underlying contract. On the other hand, in the United Kingdom, the fraud standard is more complicated and harder to achieve since the scope of the fraud rule is restricted to fraud in documents only and not extended to cover fraud in the underlying contract. Such a strict and literal approach is derived from UCP rules to maintain the integrity of $(\mathrm{L} / \mathrm{C})$ and to keep the power of the independence principle. At the same time, the US and Jordanian courts works based on the principle of equal distribution of protection, even if this contradicts the legal texts and rules of the UCP. This study has found a problem in the approach pursued towards the fraud standard in Jordan. On the one hand, it is indisputable that applying the solely realistic reason test is a successful step taken by the Jordanian courts, in the case where no bona fide holder is involved and in the absence of a confirming bank, or when the issuing bank has not paid the credit amount yet. There would be no problems regarding the reimbursement of issuing or conforming banks if this test is applied in such a situation. While on the other hand, applying the solely real reason test by Jordanian courts where a bona fide holder is involved would strike the safety position of the issuing or conforming banks in the letter of credit. The Jordanian courts, in some cases, had utterly neglected the fact that when an injunction grants to the applicant to withhold the issuing bank from honouring the payment, sometimes, the confirming bank may have already fulfilled its obligations and honoured the payment in good faith. The Jordanian courts seems completely neglected that fact and still issued an injunction to withhold the issuing bank from reimbursing the confirming bank, which had appropriately fulfilled the obligation delegated to it in good faith. Furthermore, this practice contradicts Article 35 of the UCP 600, which stated that confirming bank must honour or negotiate, reimburse the nominated bank, or confirming the bank under all circumstances. Hence this practice will result in losing the letter of credit marketability and reputation. Traders and banks may abandon letters of credit due to the potential risks that they may face if they choose it as a payment method to settle down international sale contact. Thus, Jordan needs a comprehensive regulation that addresses the standard of the fraud exception, a statute that combines the UCP 600, Article 5-109 of UCC, and articles 15,19,20 of the UNCITRAL Convention. The researcher strongly recommends the Jordanian lawmaker issue, based on the bank's practice, a comprehensive regulation due to the lack of legal rules regarding L/C in Jordan. Furthermore, the International Chamber of Commerce should keep in mind that their method has been demonstrated to be unproductive from a Jordanian perspective and, therefore, draft some articles to legalize the fraud exception in their following publications and revisions. 


\section{Appendix}

Interviews have been conducted during the period between August - November 2019. seven banks, three lecture, and three Jordanian Judges have been interviewed.

\section{Questions to the Jordanian Judges (Arabic \& English)}

\begin{tabular}{|c|c|}
\hline $\begin{array}{l}\text { Q 1: Is fraud an exception to the rule of independence } \\
\text { in the documentary credit? }\end{array}$ & الأستقلالية في في الاعتماد الاحتيال استثاء على قاعدة \\
\hline $\begin{array}{l}\text { Q 2: Does the Jordanian judge follow the provisions of } \\
\text { the Jordanian civil law about fraud? }\end{array}$ & 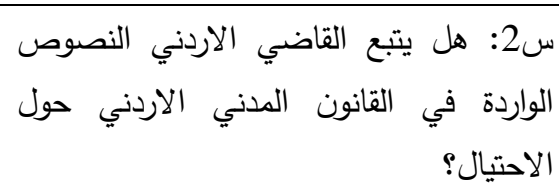 \\
\hline $\begin{array}{l}\text { Q 3: Is it necessary to rely on fraud to reject non- } \\
\text { conforming documents or does submitting non- } \\
\text { conforming or wrong documents allows the bank not } \\
\text { to pay? }\end{array}$ & 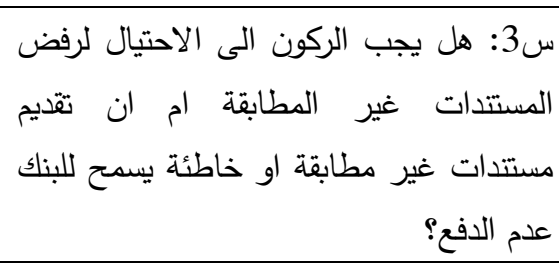 \\
\hline $\begin{array}{l}\text { Q 4: Is intent a prerequisite of the rule of fraud in Jor- } \\
\text { dan? }\end{array}$ & 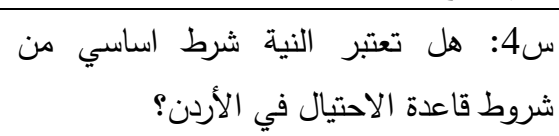 \\
\hline $\begin{array}{l}\text { Q 5: What is the fraud seen by the judge mechanism to } \\
\text { stop payment. Is it fraud in documents or fraud in the } \\
\text { base contract or both? }\end{array}$ & 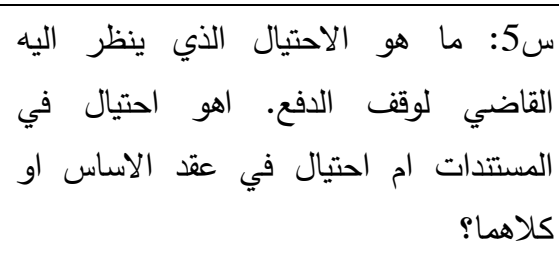 \\
\hline $\begin{array}{l}\text { Q 6: What are the conditions for granting a judicial or- } \\
\text { der to stop payment, and does the presence of a good } \\
\text { faith factor affect the judge's decision? }\end{array}$ & 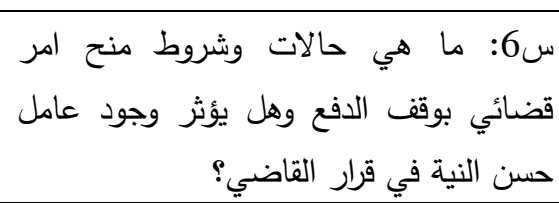 \\
\hline $\begin{array}{l}\text { Q 7: Should the Standard Customs Bulletin contain a } \\
\text { fraud rule? }\end{array}$ & 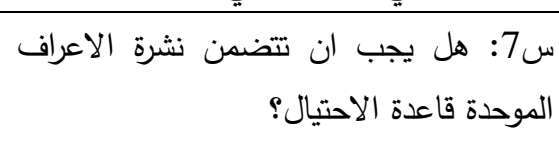 \\
\hline $\begin{array}{l}\text { Q 8: Is the absence of the legal text negative or posi- } \\
\text { tive? }\end{array}$ & إيجابي او سلبي؟ هل غياب النص القانوني هو امر \\
\hline $\begin{array}{l}\text { Q 9: What are the criteria in the Jordanian judiciary } \\
\text { regarding the nature of the fraud rule? }\end{array}$ & 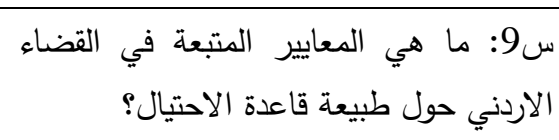 \\
\hline $\begin{array}{l}\text { Q 10: Does the Jordanian judiciary take new excep- } \\
\text { tions to the rule of fraud such as nullity, negligence or } \\
\text { lack of awareness? }\end{array}$ & 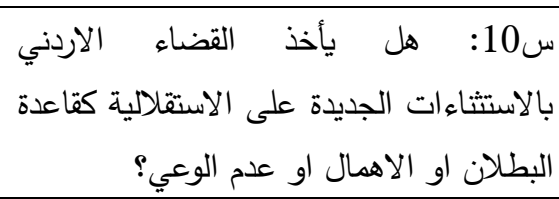 \\
\hline $\begin{array}{l}\text { Q 11: What are the solutions proposed by the judge to } \\
\text { alleviate the problems of documentary credit? }\end{array}$ & 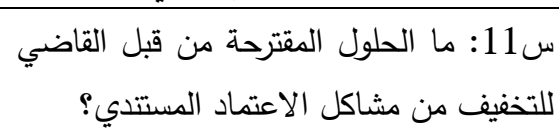 \\
\hline
\end{tabular}




\section{REFERENCES}

Abdallah Alrabei, Ali Mahmoud. "Perception of Jordanian Banks Employees on the Relationship between Accounting Information Quality (AIQ) and Documentary Credits." International Journal of Applied Business and Economic Research 15, no. 26 (2017): 409-19.

Al-Amaren, Emad Mohammad, Che Thalbi Bt Md Ismail, and Mohd Zakhiri Bin Md Nor. "The Blockchain Revolution: A Game-Changing in Letter of Credit $(1 / \mathrm{C})$ ?" International Journal of Advanced Science and Technology 29, no. 3 (2020): 6052-58.

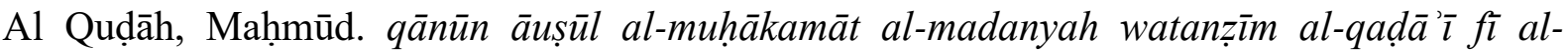
àurdun". Amman: Dār al-Thakafah for Publishing and Distributing, 1992.

Al Kharābshih, Isrā'. ' al-ghuṣh fì al 'qd al-āsāsī kā-istithnā' 'lá mabdā' al- istiqlāl fì al-i 'timād al-mustanad $\vec{\imath}$. Master's Thesis., University of Jordan, 2010. http://search.mandumah.com/Record/555162

Aladwan, Zaid. "The Implementation of the Fraud Exception Rule: A Comparative Study." Journal of Financial Crime 27, no. 3 (2020): 977-93. https://doi.org/10.1108/JFC-022020-0016.

Alavi, Hamed. "Autonomy Principle and Fraud Exception in Documentary Letters of Credit, a Comparative Study between United States and England." International and Comparative Law Review 15, no. 2 (2018): 47-68. https://doi.org/10.1515/iclr-2016-0035.

. "Mitigating the Risk of Fraud in Documentary Letters of Credit." Baltic Journal of European Studies 6, no. 1 (2016): 139-56.

- "Remedies to Fraud in Documentary Letters of Credit: A Comparative Perspective / Opravné Opatrenia Pri Podvodoch S Dokumentárnymi Akreditívami: Komparatívna Perspektíva." EU Agrarian Law 5, no. 1 (2016): 1-13. https://doi.org/10.1515/eual-20160001.

Alawamleh, Kamal Jamal Awad. "Documentary Credits and Independent Guarantees: A Critique of the 'Fraud Exception' Position in English and Jordanian Law." University of Central Lancashire, 2013.

Buckley, Ross. "The 1993 Revision of the Uniform Customs and Practice for Documentary Credits." The George Washington Journal of International Law and Economics 28 (1994): 265.

Buckley, Ross P, and Xiang Gao. "Development of the Fraud Rule in Documentary Credit Law: The Journey So Far and the Road Ahead." U. Pa. J. Int'l Econ. L. 23 (2002): 663.

"The Development of The Fraud Rule in Letter of Credit Law: The Journey So Far and The Road Ahead." U. Pa. J. Int'l Econ. L 23, no. 4 (2014): 663-712.

Chathura Warnasuriya. "Fraud Unravels All; Do Fraudulent Documents Invalidate A Letter of Credit? Chathura Warnasuriya $\square . "$ KDU Law Journal 1, no. 1 (2021): 17-31.

CheHashim, Rosmawani, and Nurul Shahnaz Mahdzan. "Fraud in Letter of Credit Transactions: The Experience of Malaysian Bankers." International Journal of Law, Crime and Justice 42, no. 3 (2014): 224-36. https://doi.org/10.1016/j.ijlcj.2014.01.008.

Dalhuisen, Jan H. Dalhuisen on International Commercial, Financial and Trade Law. 2nd ed. Hart Publishing, 2004.

Decision issued by Jordanian Court of Cassation, no 1215/2005. 
Decision issued by Jordanian Court of Cassation, no 835/2004.

District court of Amman Decision No. 407/2009.

Helo, Kamal Jamal Alawamleh and Shadi Helo Abu. "Fraud in the Documents and the Underlying Contract in Letters of Credit under Jordanian and English Law: A New Prerequisite?" Journal of Financial Crime, 2020.

Hwaidi, Mohd. "Four Uncertainties around the Fraud Exception in Documentary Letters of Credit under English Law." The Journal of International Maritime Law 12, no. 732 (2012): 39-56.

ICC, International Maritime Bureau of the. Trade Finance Fraud: Understanding the Threats and Reducing the Risk: A Special Report. Paris: Distributed by ICC, 2002.

International Chamber of Commerce, Documentary Credits Regulations "Uniform Custom and Practice," No. 600 (2007).Islam, Shohana and Ahamed, Shamim. "Preventing Letter of Credit Fraud." DIU Journal of Business and Economics 3, no. 2 (2008): 1-12.

Jordanian Civil Law No. 43 of 1976.

Judge Mohammed Al Amareen, An Active Judge in court of appeal (Irbid- Jordan). Interview by author, Irbid-Jordan, August 13, 2019.

Judge Saeed Ajlouni, An Active Judge in the court of First instance (Irbid- Jordan) Interview by author, Irbid-Jordan, August 14, 2019.

Judge Zaid Sanosi, An Active Judge in court of appeal (Irbid- Jordan) Interview by author, Irbid-Jordan, August 12, 2019.

Meral, Nevin. "The Fraud Exception in Documentary Credits: A Global Analysis." Ankara Bar Review 39, no. 2 (2012): 41-76.

Mohammad, Emad, and Al Amaren. "Documentary Letter of Credit in Conventional and Islamic Banks in Jordan Documentary Letter of Credit in Conventional and Islamic Banks in Jordan," no. April (2020).

Monteiro, Felicity. "Documentary Credits: The Autonomy Principle and the Fraud Exception: A Comparative Analysis of Common Law Approaches and Suggestions for New Zealand." Auckland University Law Review 13 (2007): 144-70.

Rafique, Rushmila Bintay, and A. Vijayalakshmi Venugopal. "Preventive Measures To Mitigate the Risk of Fraud in Letters of Credit Transactions in Malaysia." UUM Journal of Legal Studies 12, no. 2 (2021): 27-49. https://doi.org/10.32890/uumjls2021.12.1.2.

Rutten, Lamon. "A Primer on New Techniques Used by the Sophisticated Financial Fraudsters with Special Reference to Commodity Market Instruments." UNCTAD 11 (2003): 7.

Soehartono, Kukuh Tejomurti, Arsyad Aldyan, and Rachma Indriyani. "The Establishing Paradigm of Dominus Litis Principle in Indonesian Administrative Justice." Sriwijaya Law Review 5, no. 1 (2021): 42-55. https://doi.org/10.28946/slrev.Vol5.Iss1.603.pp42-55.

The unified commercial code of the United States, 5-109 "Forgery and Fraud".

Tolia, Ioanna. "Recognized Exceptions to the Autonomy Principle in Documentary Letters of Credit: A Global Analysis," no. February (2018).

United Nations, "United Nations Convention on Independent Guarantees and Standby Letters of Credit." (1996).

Wang, Baojie. "Discussion on Internationalization of Punishment of L/C Fraud and Legal 
Remedy." Politics and Law 87 (2005): 87-88.

Xiang, Gao, and Ross P. Buckley. "A Comparative Analysis of the Standard of Fraud Required Under the Fraud Rule in Letter of Credit Law." Duke Journal of Comparative \& International Law 13 (2003): 293-336.

Zhang, Yanan. Approaches to Resolving the International Documentary Letters of Credit Fraud Issue, 2011.

- "Can Soft Clauses in Letter of Credit Transactions Be Considered Letter of Credit Fraud in China? By Nordic Journal of Commercial Law to the Buyer and Seller . 2 The Terms and Conditions Governing Letter of Credit Transactions Are Issued by the Internatio." Nordic Journal of Commercial Law 15, no. 1 (2011): 1-20. 